\title{
Review
}

\section{Scientists’ virtues matter. More than ever}

\author{
Alessandro Delfanti \\ Steven Shapin, The scientific life. A moral history of a late modern vocation, The University of \\ Chicago Press (2008).
}

\begin{abstract}
In his latest book "The scientific life. A moral history of a late modern vocation", the social historian of science Steven Shapin addresses the public image of contemporary scientists, their virtues and vocations. Who are, and how they represent themselves, those scientists who work on the edge between industry and academy, and who are responsible for the radical uncertainty embedded in the contemporary production of scientific knowledge? If "people matter", as Shapin states, the genealogy he provides should encourage us to dig more deeply in the main stage of the virtues and ethos of scientists: the mass media.
\end{abstract}

In his last book the social historian of science Steven Shapin addresses the image of contemporary scientists, their virtues and vocation, especially focusing especially on the relationship between industrial and academic science. Who are, where they come from, and how they represent themselves, those scientists who work on the edge between worlds that we use to consider so separated? The genealogy provided by Shapin, as we will see, is interesting also as a point of view for scholars who study the public dimension of science.

Indeed, as Shapin states in the introduction of his The scientific life. A moral history of a late modern vocation, "people matter": the personal virtues and the ethos of contemporary scientists are central to understand their practices and institutional relationships, and they are not merely a matter of public perception unrelated to the material development of science. But there's more. In fact, the industrial R\&D laboratories and the entrepreneurial networks are places where the forces that drive science development and capitalist economy gather. There, where technoscientific futures are made, the role of scientists' personal virtues and personalities reaches its zenith. This is the main Shapin's main thesis and the lens he uses to analyse late modernity.

Nevertheless, the historical dimension of this book date back at least all along the $20^{\text {th }}$ century. The author reconstructs the clash between "the view from the tower", or the normative accounts of scientists" ethos written by the mertonian sociology, and "the view from the managers", a body of studies by organization sociologists who worked for companies whit R\&D sectors. In While doing this comparison, he turns upside down the naïve image that many academic scientists still have about their job. The Ivory Tower of science never existed in the way it was depicted during the $20^{\text {th }}$ century, let alone the complexity of $21^{\text {st }}$ century reconfigurations of science institutions. The difference between the goals of academic science - the truth - and industrial science - profit - is an artificial separation between two worlds which that needed different public images but at the same time shared several characteristics.

Though, Shapin is not arguing that we should throw away any scientific ethos and accept the flatter and poorer view of the scientists as moral ordinary people. But the "managerial ethos" imposed on American - and increasingly on European - universities is at least a misrepresentation: late capitalism and its informational and innovative strains are embracing new ways of managing creative people such as scientists - for example, classical practices of open science such as data sharing, anti-hierarchy, open publishing. So, when he writes about the professed altruism or moral virtues of scientist, Shapis is underlining the importance of personal reputation for people who deal with the "radical uncertainty" of the techno-scientifical enterprise in a world where speaking of nature and technology means speaking in behalf of the future as well. The book ends - not by chance - with the description of a sunny day in San Diego, where 200 scientists, biotech and high-tech entrepreneurs, venture capitalists, intellectual 
property lawyers and other path-breaking species of the knowledge society ecology were meeting and networking by the beach.

Nevertheless, coming to the communicative side of this review, the "how to network" aptitude of contemporary scientists, their reputation, their ability to represent themselves, are not merely staged in private spaces. In fact, media are the main arena that allow scientists to show their personalities, moral values and ways of participating in the building of a future which future that is embedded in the scientific enterprise. Shapin do not address explicitly this side of the problem, but the way in which mass media paint the public images of scientists seems to be one of the mines we should dig in order to understand the relationship between their virtues and ethos, and the institutions of contemporarity.

HOW TO CITE: $\quad$ A. Delfanti, Scientists' virtues matter. More than ever, Jcom 08(01) (2009) R02 